\title{
TRANSPORT POLICY AND LANDLOCKED COUNTRIES: HOW TO MINIMIZE GEOGRAPHICAL HANDICAP AND KEEP ABREAST OF GLOBAL BUSINESS COMPETENCES
}

\author{
DOI: http://dx.doi.org/10.18509/GBP.2019.41 \\ UDC: 339.13:338.47(4-11) \\ 339.13:338.47(497.7)
}

\author{
Riste Temjanovski \\ University “Goce Delcev"- Stip, Faculty of Economics, North Macedonia
}

\begin{abstract}
This article examines geographical and non-geographical problems and difficulties that landlocked developing countries coped in regional and global sphere to strength global market competition, with primarily focus on Republic of Macedonia.

The landlocked countries are seen as "geographical handicap" or "victims of geography" are countries without sea access, insulated from beneficial flows of better transport, transit and trade accessibility to preferred location.

Efficient transit transport is crucial for landlocked nations. Due to their lack of territorial access to seaports and the prohibitive cost of airfreight, landlocked countries have to rely on the transport of goods by land through one or more neighboring countries. Despite the unfavorable geographical location, landlocked developing countries have insufficiently developed transport infrastructure, but also face other non-geographical factors, such as unregulated foreign policy with neighboring countries, certain trade restrictions, unsatisfactory institutional infrastructure, absence from regional integration ties, political crisis etc. The additional costs incurred together with problems of distance, make imports more expensive and render exports less competitive, thus putting landlocked countries at a disadvantage in the global economy.

Today, in this context, when access to global markets is a necessary than ever, the main question is how "landlocked countries" should optimize their transport policy up to date with all the global events and developments, to develop their market competitiveness and management chain procurement.
\end{abstract}

Keywords: geographical handicap, landlocked, transit, transport policy, global market

\section{INTRODUCTION}

Recent decades have seen enormous and tectonic changes in the world. But, always all developments in the world are continuously linked to geography. World processes are the typically "geographical" colored. Geographic, cultural, and institutional proximity leads to special access, closer relationships, better information, powerful incentives, and other advantages in productivity and innovation that are difficult to transmit from a distance. Economic geography has changed at all spatial scales. Now more than ever before, the world economy becomes complex, knowledge based, and dynamic.

While some developing nations continue to reap the rewards of globalization, a significant number of countries continue to lag behind. Among this group are the world's 32 landlocked developing countries (LLDCs), who find themselves structurally disadvantaged mainly due to geography and its attendant drawbacks. Yet LLDCs still face high trading costs and continue to have challenges in improving their 
competitiveness. They continue to contend with the structural constraints such as the lack of productive capacities high commodity dependence together with the impact of the economic and financial crisis. [1]

Today, in this context, when access to global markets is a necessary than ever, the main question is how "landlocked countries" should develop their transport policy up to date with all the global events and developments, to develop their market competitiveness and management chain procurement.

According to Faye [2] Landlocked countries not only face the challenge of distance, but also the challenges that result from a dependence on passage through a sovereign transit country, one through which trade from a landlocked country must pass in order to access international shipping markets. While rivers were a more common form of trade transit in Smith's time, the principle of dependence on neighbours applies equally to the more modern transport modes of roads and railways. Such dependence can take several forms, many of which are less deliberate than the power politics suggested by Smith.

Furthermore, for the landlocked countries, problems of distance are substantially compounded by the need to cross international borders and by the inability to regulate the through transport process. As a result of these disabilities, the delivered costs of imports are higher, exports less competitive and attraction for foreign direct investment reduced. Gotcheva [3] argue that one of the most striking features of landlocked countries is their dual vulnerability; i.e. they are vulnerable on their own account and on account of being dependent on one or more transit countries. Not only are they deprived of access to the sea but their neighbouring countries often have little interest in making the flow of goods across their borders easy for them. In fact, their neighbouring countries may additionally have economic or military incentives to block their access to the sea or transit through their territory.

According UN report the annual GDP growth rate of the LLDCs is estimated to have decreased from $6.7 \%$ to $5.9 \%$ between 2010 and 2011. The highest GDP growth rate was recorded by Mongolia (17.3\%) and Turkmenistan (14.7\%) in 2011. The lowest GDP growth was recorded by Azerbaijan (1\%) and Swaziland (1.3\%). GDP is estimated to have further decelerated to $4.9 \%$ in 2012. The average GDP per capita for LLDCs in 2011 was 1,414 in constant 2005 US\$. The lowest GDP per capita was recorded by Burundi (US\$ 186) and Ethiopia (US\$ 270). The highest was recorded by Botswana (US\$ 6,168) and Turkmenistan [4].

How to resolve this bitter problem. Consequently, the development gap between these countries and the rest of the world is widening. It is unquestionable that excessive transit costs have become more a significant barrier than tariffs. Whether the solution is just to improve the transport infrastructure. What about political issues neighbouring countries; way of attracting FDI; doing business, managing logistics activities, improve competitive amenities.

\section{LANDLOCKED PROBLEM SUCH AS INTERNATIONAL QUESTION}

Landlockedness refers to the geographical situation of a country without direct access to the sea, or landlocked countries, i.e. countries without direct coastal access to the sea and thus also to maritime trade, face very specific challenges. International law, including the 1965 Convention on Transit Trade of Landloked States, has provided a framework around which may be constructed appropriate mechanism for overcoming the handicaps inherent in a Mediterranean location. These handicaps are shared by other developing countries in 
varying degrees, but the combination of small size, povery, weakness and isolation makes the developing landloked states truly distinctive in the modern world. [5].

Owing to geographic and other related attributes, landlocked developing countries are confronted with a range of special constraints that inhibit their full participation in the globalization process. Lack of access to the sea and remoteness from major international markets result in high transit costs, creating dreadful obstacles in importing and exporting goods, which itself puts its stamp on the overall level of living standards.To give appropriate emphasis to the continuing problems faced by landlocked and transit developing countries and the need to improve their transit transport systems, the General Assembly adopted resolution 56/180 of 21 December 2001 [6] on specific actions related to the particular needs and problems of landlocked developing countries, by which the Secretary-General was requested to convene an international ministerial meeting on transit transport cooperation.

To fulfillment the goal and to overcome the gap starving the landlocked countries, by resolution 57/242, the General Assembly also requested the Secretary-General of the Conference to organize, in close cooperation with the regional commissions, a number of intergovernmental regional and subregional meetings as part of the preparatory process for the Ministerial Conference.

The framework of recommendations and action plan were subsequently reviewed and endorsed by the Commission at its 59th session (first phase) on 24-25 April 2003 as the regional platform to be submitted to the International Ministerial Conference. The key issues contained in the action plan are summarized as follows:

- Policy-related actions;

- Improved coordination within and between countries;

- Trade and transport facilitation;

- Promoting competition in the provision of transit transport services;

- Better monitoring;

- Enhancing transit infrastructure;

- Capacity-building and human resources development for transit transport:

According to definition of Landlocked, there are 44 landlocked countries in the world. Of these, the United Nations lists 32 as landlocked developing countries that are lowand middle-income countries based on the World Bank country classification (henceforth referred to as landlocked developing countries, LLDCs) with a population of nearly 440 million. [7] Based on the World Bank country classification, the LLDCs fall into the low, lower-middle and upper-middle income categories (Azerbaijan, Botswana, Kazakhstan, Serbia, Macedonia and Turkmenistan are the upper-middle income countries in the list of LLDCs).

Despite the fact that the landlocked states have done worse as a result of their distinctive geographic handicape, some States in Western and Central Europe such as Switzerland, Austria, the Czech Republic, Hungary and Slovakia have some way to go to economic and social welfare.

\section{ECONOMIC ANALYSIS OF DISADVANTAGES BY LANDLOCKED COUNTRIES}

Efficient transit transport is crucial for landlocked nations. Due to their lack of territorial access to seaports and the prohibitive cost of airfreight, landlocked countries have to rely on the transport of goods by land through one or more neighboring countries. The additional costs incurred together with problems of distance, make imports more 
expensive and render exports less competitive, thus putting landlocked countries at a disadvantage in the global economy.

For most developing countries, transit transport is most heavily constrained by delays and costs incurred at border crossings. Time-consuming border crossing and customs procedures, complicated non-standard documentation, poor organization and a lack of skills in the transport sector are some of the major contributory factors. Overlapping obligations brought about by several bilateral, trilateral and subregional agreements, and the lack of a harmonized legal regime for transit transport, including arrangements for transit fees, further compound the complexity of the transit transport process. Unfortunately, consistent information isolating the causes of these constraints and quantifying the costs and time they add to the transit process, as well as their impact on the economies of landlocked countries, is not available to policy makers. Another factor leading to significant increases in the costs of transit transport for landlocked countries is the return of empty containers to points of origin, a reflection of the present imbalance in trade of landlocked countries and the lack of logistics facilities near borders. [8] Recent OECD research suggests that investment in physical infrastructure (high-speed rail links, airports, waterways and major efforts to improve road infrastructure) can boost long-term economic output by more than other types of investment. [9]

Sach and Warner [10] argue whether a country's geography affects growth. Countries that are geographically isolated from world markets will face higher costs for all international activities, and may end up with a lower division of labor and lower output per capita. Landlocked countries, in particular, face very high costs of shipping, since they must pay road transport costs across at least one international boundary in addition to sea freight costs. Although air shipments can help overcome many of these problems, only certain goods can be economically shipped by air, and most countries still import and export the majority of goods by the sea.

According the World Trade Report (2013) [11] transportation costs drive a wedge between origin and destination prices, so higher transportation costs will reduce the volume of trade. Furthermore, if transportation costs are charged on a per unit basis rather than simply proportionately to the price of the traded good, higher transportation costs will tend to decrease the share of low-quality goods and goods with low value-to-weight ratios in international trade. Declining transportation costs can increase the range of goods available for international commerce. For example, estimates from Latin American countries suggest that a 10 per cent decline in average transport costs would be associated with an expansion of more than 10 per cent in the number of products exported, and a 9 per cent increase in the number of products imported. Transport costs are also timesensitive, and this has become more important with the rise of international supply chains, just-in-time inventory management and lean retailing. Lack of competition and bigger transport costs are limited factors for global market. Lack of competition in maritime transport means developing countries pay as much as 30 per cent more in freight charges and consequently have some 15 per cent less trade. Significant efficiency gains are likely to result from increased competition. In the case of air transport, studies of open skies agreements tend to find that they lead to reduced transport prices and increase cargo quantities.

The consequence of the lack of access to the sea means that it is far more expensive to import essential items and export goods. It is estimated that the basic import and export costs of the landlocked developing countries are nearly twice those of their transit neighbours. On average, it costs $\$ 3,040$ to export a standardized container of cargo from 
a landlocked developing country, whereas their coastal neighbours spend around $\$ 1,268$, according to data provided by the World Bank. Likewise, it costs a country like Burundi $\$ 3,643$ to import a similar container of merchandise compared to its coastal neighbours in east Africa who pay only $\$ 1,567$. While the the Almaty Programme of Action (APoA) has been successful in galvanizing global support for LLDCs in the areas of financial and technical assistance as well as macroeconomic policy development a disaggregated analysis reveals a different picture: progress is uneven, and the sustainability of the gains is not apparent. [12]

The role of transport in decisions made by businesses on where to locate or relocate is a crucial element in our ability to assess the impact of our transport system on people's lives. The review notes that large-scale transport infrastructure policies are likely to be successful in supporting latent growth in under-developed regions, but is likely to be ineffective in stimulating new growth. Related to this issue is that transport is important in business relocation only when the decision to move has already been taken. [13]

\section{MACEDONIAN TRANSPORT HANDICAP AND CORE EUROPEAN MARKET ACCESS}

Republic of Macedonia is a landlocked country located in the south-central part of the Balkan Peninsula. Country area is 25.713 sq. km bordering with two EU member states: in the south Greece and in the east - Bulgaria. The neighbor in the north is Serbia and Kosovo, and Albania in the west.

The transport sector has a key role in the national economy. In addition, the Republic of Macedonia should take advantage of its position, because such as South-East European country, it is at intersection of routes to Balkans, Mediterranean and Caspian Region and Asia. Republic of Macedonia is promoting the concept of EU Neighborhood Policy into the transport field for better connection the EU with the neighboring countries and regions. External links include all direct links of the Country with neighboring countries, as they manifest the most direct relations as parts of the obligations to develop good neighbor relations and intensive exchange and cooperation with the surrounding.

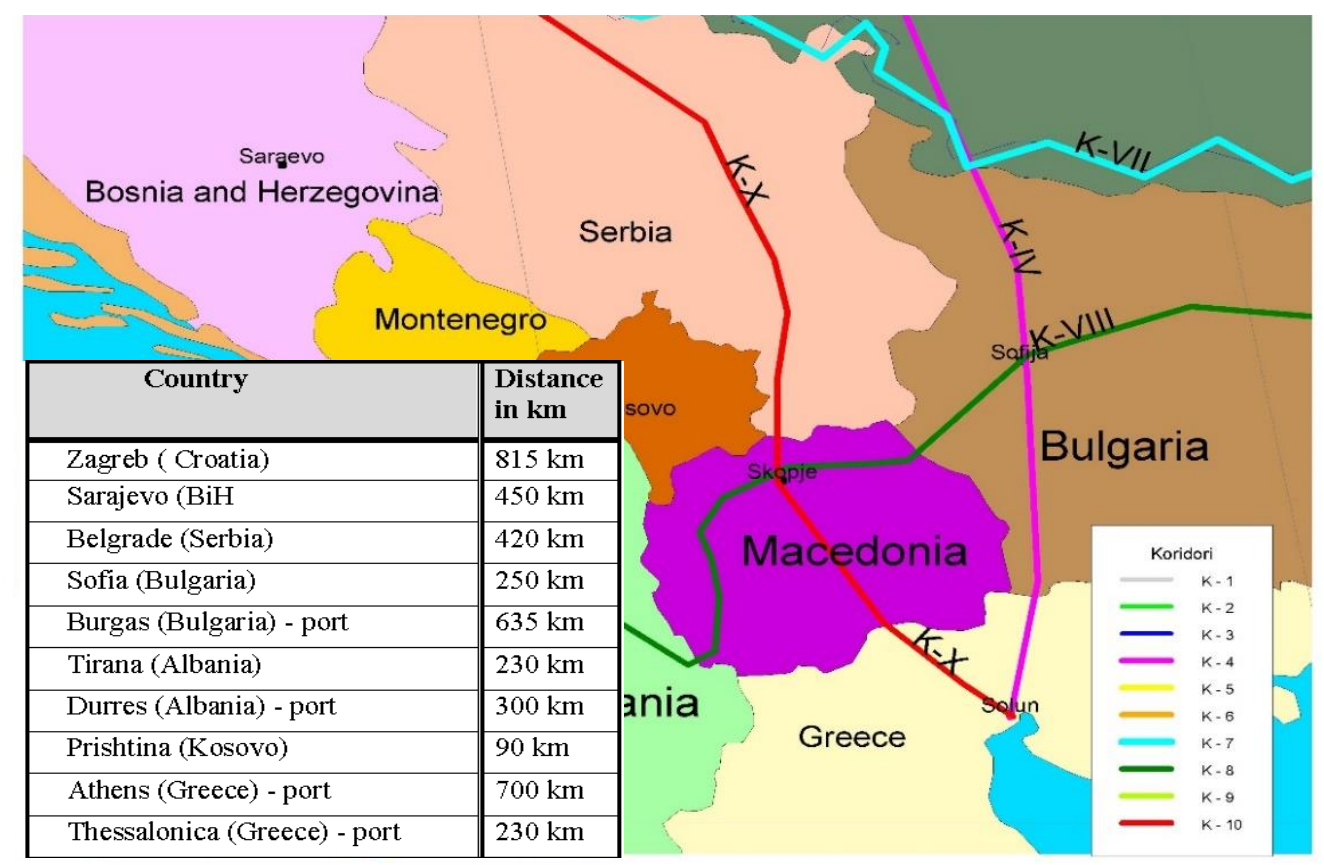

Figure 1. Distances from major destinations 
The major transnational axes are those which contribute most to promote the international exchanges and traffic as well as to enable regional cooperation and integration. The South-Eastern axis which are passing through Republic of Macedonia, fully are covering the existing defined Corridor X and VIII. On the existing Corridor X, with a total length of $172 \mathrm{~km}$, passing the country in North - South direction; at about $71 \%$ has been already finalized to modern highway standards and the remaining sections accounting $29 \%$ of the total being ready for tender procedures. [14]

On the existing Corridor VIII, with a total length of $304 \mathrm{~km}$, crossing the country from East to West, is less advanced in comparison to Corridor X. Only $36.3 \%$ of the total length is already built to modern highway standards. Corridors VIII and X are expected to be ones of the impulses to generate economic development among countries of Western Balkans. In other hand, they also play a main role in domain the Economic and Environmental Programs in this regional policy. These corridors would be assisted by the establishment of set of multilateral principles and encourage the transfer of passenger and goods.

The European Community is supporting the implementation of these projects to attain greater, efficient transport system whish reduce regional disparities and effective better balance between European countries.

There is strong political commitment to the development of the regional transport networks is confirmed with the signing of the Memorandum for understanding of the development of the South-East Europe Core Regional Transport Network in June 2004. More recent efforts for defining the Core Regional Transport Network are made with in the future Treaty for Establishing a Transport Community between the EU and SouthEast Europe Partners which should be in force by 2011.

\section{MACEDONIAN TRANSPORT AND TRADE POLICY AND VULNERABILITY OF LANDLOCKED POSITION}

One mode of transport is consistently predominant in transport and trade of passengers and goods. Road transport was the main mode of transport used for trade with European countries. The analysis of external trade shows that road transport was by far the most used mode of transport for trade. The last decades road transport was the main mode of transport with participation for $93 \%$ of exports and $94 \%$ of imports by value (the same transport mode participate with $71 \%$ of export by volume and $72 \%$ of import by volume). Second mode of transport, rail transport accounted only between $10-25 \%$ by volume and between $2-10 \%$ by value. In 2014, rail transport participated in value export with $4.89 \%$, and $1.94 \%$ in value import. The volume of goods exported from the R. Macedonia by rail between 2010 and 2014 increased, from $10.03 \%$ (2010 volume export) to $25.03 \%$ in export and from $12.66 \%$ (2010 volume import) to $17.32 \%$ volume import.

Table 3: Modal split in Macedonian trade in terms of value-volume; export-import

\begin{tabular}{|c|c|c|c|c|c|c|c|c|}
\hline & \multicolumn{2}{|l|}{ value export } & \multicolumn{2}{|l|}{ value import } & \multicolumn{2}{|l|}{ volume export } & \multicolumn{2}{|l|}{ volume import } \\
\hline & USA \$ & $\%$ & USA \$ & $\%$ & $\mathrm{~kg}$ & $\%$ & $\mathrm{~kg}$ & $\%$ \\
\hline Rail & $127,413,312$ & 4.89 & $95,698,453$ & 1.94 & $1,462,612,150$ & 25.03 & $1,260,356,741$ & 17.32 \\
\hline Road & $2,445,472,510$ & 93.93 & $4,648,029,343$ & 94.21 & $4,200,268,573$ & 71.88 & $5,324,419,078$ & 73.17 \\
\hline Air & 254,917 & 0.01 & $20,985,986$ & 0.43 & 809,416 & 0.01 & $120,463,471$ & 1.66 \\
\hline Mail & 2,313 & 0 & 280,824 & 0.01 & 19,549 & 0 & $2,462,215$ & 0.03 \\
\hline Pipeline & $18,427,617$ & 0.71 & $30,373,153$ & 0.62 & $103,043,444$ & 1.76 & $251,309,059$ & 3.45 \\
\hline Others & $11,840,069$ & 0.45 & $138,476,790$ & 2.81 & $76,330,297$ & 1.31 & $317,718,639$ & 4.37 \\
\hline & $2,603,410,738$ & & $4,933,844,549$ & & $5,843,083,430$ & & $7,276,729,202$ & \\
\hline
\end{tabular}


The volume and value of export by air is $0.01 \%$, mainly on account of the volume of goods traveling by air with EU-28, but because of the small volume of this trade, the participations is not as significant as it appears. By contrast, imports by air scope by $0.43 \%$ (by value) and $1.66 \%$ (by volume) over the five years' period, with EU-28 as the main trading partners.

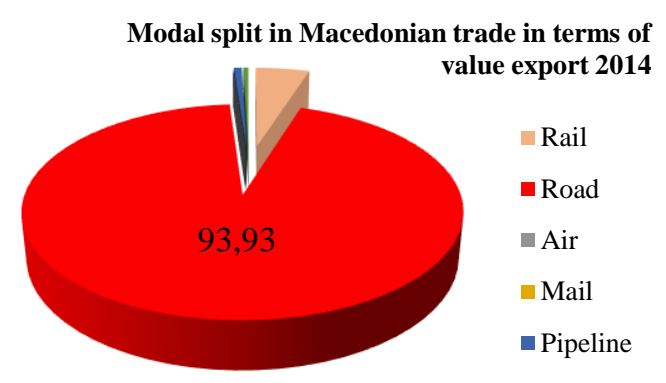

Modal split in Macedonian trade in terms of volume export - 2014

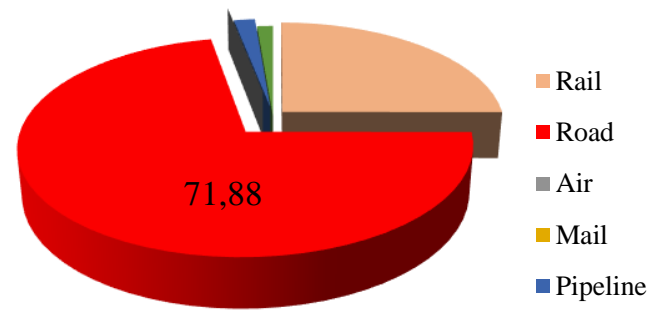

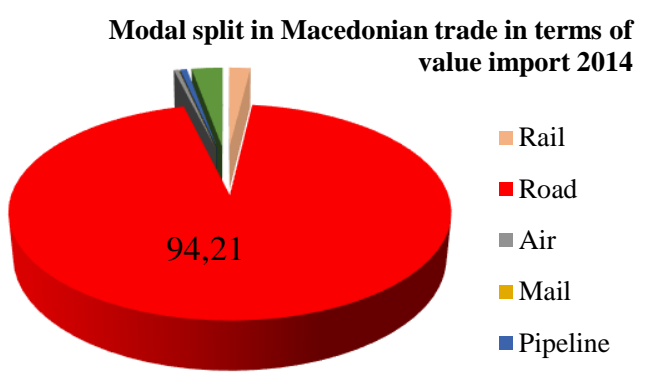

Modal split in Macedonian trade in terms of volume import 2014

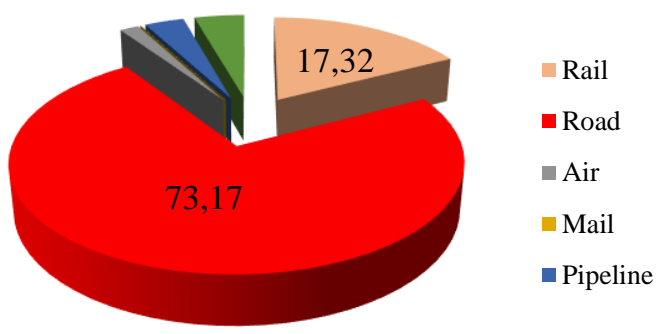

Figure 2: Modal split in Macedonian trade in terms of value-volume; export-import Source:[15].

The general conclusion from ever presented analyzes on the participation of individual types of transport in the total turnover of the Republic of Macedonia in the foreign exchange is the dominant share of road transport, and the second place share of rail transport, while other types of traffic such as air and combined transport, does not meet today's needs, considering their participation and importance as the countries with developed transportation systems. Imbalances and structural discrepancies in the transport system require overcoming this disadvantage. The fact that Macedonia is a landlocked an additional limiting factor in the development of maritime transport, which dominates the trade of EU countries, then, Serbia, Turkey, China, USA and Russia.

It is evident that the share has grown over the decades: first, because over time Macedonia became more and more dependent on the EU in trade terms, substituting for the traditional lost eastern markets after gaining independence from Yugoslavia; second because the EU has been enlarging itself (mainly with the large wave of enlargement in 2004, 2007 and 2013).

The trade share with the EU amounts to about two thirds of the whole trade $(61.4 \%$ of imports and $69.6 \%$ of exports with EU-28). Interestingly, an additional $12 \%$ to $25 \%$ of total trade is conducted with the other countries of the Western Balkan. Given that these countries are themselves very much dependent on the trade with the EU, it appears that in trade terms Macedonia is almost entirely dependent on the EU. To drive growth, Macedonia remains heavily reliant on external factors, especially trade with Germany, which now takes over $40 \%$ of Macedonian goods exports, where volume share with $35.8 \%$ in export, and $10.5 \%$ in import of goods, and followed by. [16] 
The problem can be compounded with interstate political relations. When analyzing countries with which Macedonia has the highest trade (Germany, Great Britain, Greece, Serbia and Bulgaria) [17], it can be concluded that the strategic interest of our country's transport Nord-South axis, via which the communication to these markets.

For the Republic of Macedonia, as a landlocked country, there are still fresh memories of problems related to blockades imposed on or from neighboring countries.

Trade and transit sanctions against Serbia introduced the summer of 1992 from United Nations (UN), that our country was obliged to implement it and apply, and by the closure of its southern border by Greece which deprive it of its access to Salonika (the Republic of Macedonia's closest and most economic outlet to the sea). Greece initially did not recognise the country name and because of that imposed a trade embargo on Macedonia.

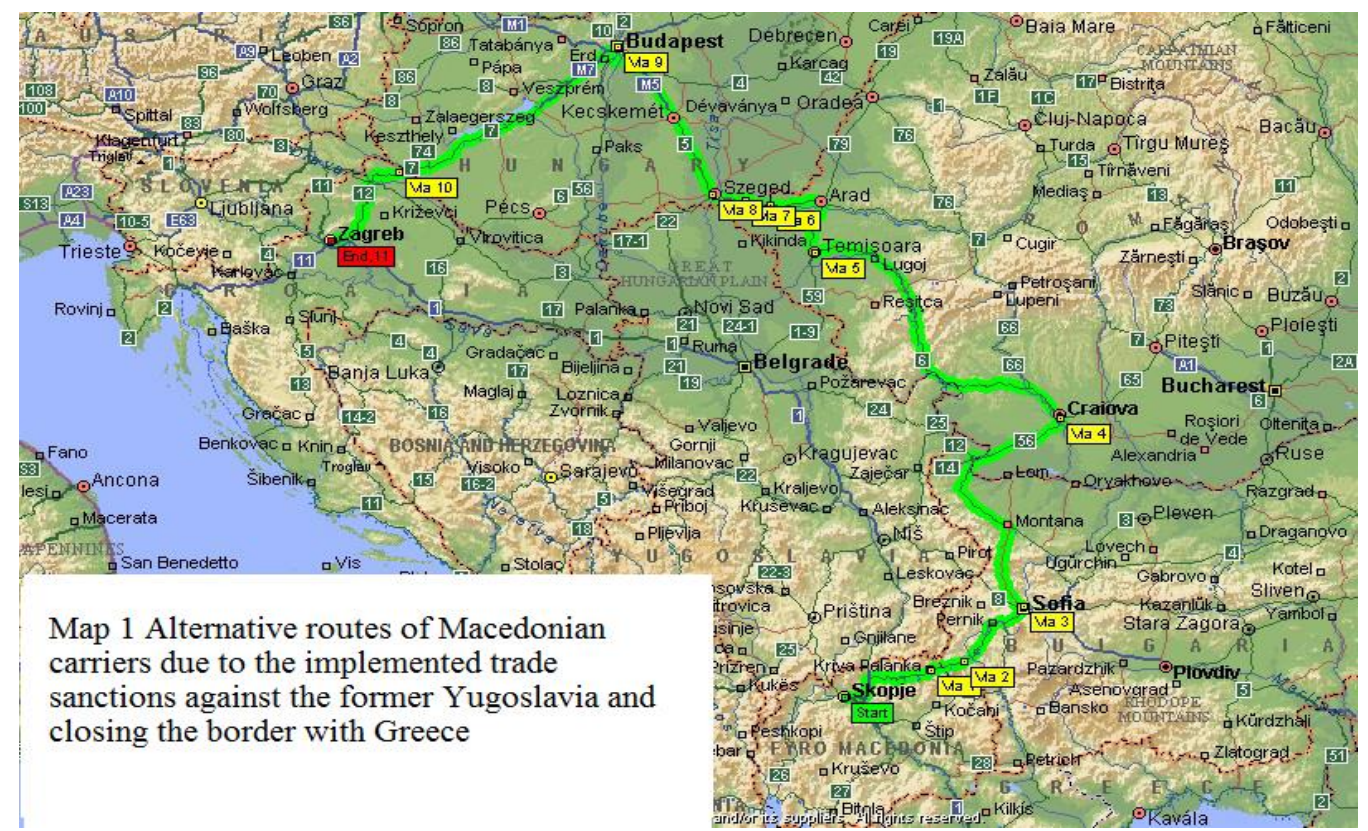

Figure 3. Alternative routes of Macedonia in time of sanctions Source: Own illustrations, graphics @2018 Google maps

The embargo, which lasted until 1995, was particularly damaging for the Macedonian economy; as a landlocked country, it is dependent on access to Greek ports. Given the importance of Serbia as a transport corridor to the countries of Western and Central Europe, these measures caused significant problems due to the transport by road of big volume stock and perishable goods. Macedonia had its products forward through alternative routes, which significantly increased transport costs. Here we can mention and other reasons, such as: poor realization of export in terms of import quotas, disorganization of the supply of our exports, inadequate sorted and weak competitive ability of the Macedonian production, certain import barriers and implementation of numerous mechanisms for restricting imports etc.

International law refers to the principle of free transit, so the problem if abstract political aspect depends on the construction of the road, railway and other transport connections and effective transportation costs. The long-term orientation towards the four geographical directions, and to all the surrounding marine ports is necessary and represents our continued interest and commitment.

Traffic at the main border crossing point Evzoni (Greece border line with Republic of Macedonia), in the past period is interrupted on frequent blockages caused by Greek 
unions (especially rail), the protests by Greek farmers, as well as the wave of refugees from the Syria, Iraq and other war and economic torn countries from Middle East and Africa.

According the considerations from National Transport Strategy, the prime strategic improvements concerning regional core network Macedonian authorities must be given on construction of new Railways sections as part of Corridor VIII - with a length of about $62.6 \mathrm{~km}$ from Kicevo to the border with Republic of Albania, as part of Corridor VIII. The construction of the western part the railway Corridor 8 on the territory of the Republic of Macedonia, will provide rail access to the ports of Durres and Vlora. Next main task is completion the eastern railway section Kumanovo - border with the Republic of Bulgaria. Further dynamics of completion of the railway line from Kumanovo to the border with Bulgaria, as well as the construction of the railway line Kicevo - Struga border with Albania, will depend on the availability of favorable foreign financial support.[18]

In Strategic geo-political priority Macedonia must dissolve and eliminate decades' problems with geographical handicap and blockades with Transport Policies and Programmes which should reflect the interaction between different modes of transport with objective-based strategies aimed at providing balanced cost-effective solutions to transport problems.

To attain better global trade position The Republic of Macedonia must strength strategic transport and foreign policy components: (i) the civil works component would improve the country's access to the ports of Bulgaria and Albania through the rehabilitation and upgrading of about $60 \mathrm{~km}$ of the East-West Corridor; (ii) the transit facilitation component will fund technical assistance and equipment for the development and implementation of a modem customs system and the improvement of transit times; and (iii) the institutional strengthening component helped with EU transport institutions will fund technical assistance and training in the area of economic evaluation of different road interventions and life-cost planning for pavement management; (iv) to resolve three decades Greece's problem with name and reinforce integration processes in EU and NATO.

\section{CONCLUSION}

This paper has given an overview of the performance of the landlocked developing economies with special overview of the Republic of Macedonia. Often disadvantage features of landlocked countries is their dual vulnerability; i.e. they are vulnerable on their own handicap and on account of being dependent on one or more transit countries. Not only are they deprived of access to the sea, but their neighboring countries often have little interest in making the flow of goods across their borders easy for them. In fact, their neighboring countries may additionally have economic or military incentives to block their access to the sea or transit through their territory.

Geographical Factors and transport infrastructure are two of the key determinants that influence international competitiveness in every country. The transport infrastructure is the bloodstream of every country, but quality of such infrastructure and how widespread is it, play an increasingly key role in attract FDI and design of business strategy on competitive sharing of the international market. Many analysis and research highlight that infrastructure investment needs to be effectively targeted to maximize overall economic benefits. In addition to making sound decisions on projects, this also depends on having appropriate regulations and price signals in infrastructure markets. 
It must move in step with the implementation of these programmes and respond with vitality and responsibility to the changes taking place in society. We must all acknowledge that, in many respects, our quality of life depends on the success of our transport policy.

As we have seen hereinbefore main task and priority for Macedonian geo-political strategy is overcoming the incoherence by rail transport infrastructure through Bulgaria to the Black Sea, or through Albania to the Adriatic port of Durres puts it in a very unfavorable position Republic of Macedonia and as soon as possible Republic of Macedonia must resolve the main problem with the lack of alternative rail connections.

\section{REFERENCES:}

[1] United Nations [2013]: The Commitment. Linking Landlocked Countries to Global Opportunities. (special future: Gyan Chandra Acharya. Unlocking the Potential of Landlocked developing Countries. [s.a.].p.3 [17.03.2017]

[2] Faye L.M. [et all.][2004]. The Challenges facing Landlocked Developing countries. Journal of Human Development. Vol.5, No. 1, March 2004. p.32.

[3] Gotcheva K. [2004] Landlocked countries: opportunities, challenges, recommendations. p.1.

[4] UN. Office of the High Representative for the least developed countries, landlocked developing countries and small island. www.un.or/ohrlls [17.03.2017]

[5] Glassner M.I. [1973]: The Status of Developing Land-Locked States Since 1965. University of Miami Inter-American Law Review. 10-1-1973. p. 494.

[6] United Nations [2003]. Economic and social commission for Asia and the Pacific. Landlocked Developing Countries Seris, No.1. Transit Transport issues in Landlocked and transit developing countries. New York, 2003. p. 1.

[7] World Bank[2014]: Improving Trade and Transport for Landlocked Developing Countries. Washington: World Bank Group, 2014. p.IX-1.

[8] United Nations [2003]: Economic and social commission for Asia and the Pacific. Landlocked Developing Countries Seris, No.1. Transit Transport issues in Landlocked and transit developing countries. New York, 2003. p. 5.

[9] OECD 2009 [2009], Economic Policy Reforms: Going for Growth, Organisation for Economic Co-operation and Development, Paris.p.24-25. [http://www.keepeek.com/DigitalAsset-Management/oecd/economics/economic-policy-reforms-2010_growth-2010-en\#page24 visited at 04.09.2016]

[10] Sachs D.J., Warner M.A. [1997]: Sources of Slow Growth in African Economies. Journal of African Economies, December 1997, Volume 6, Number 3, p. 5

[11] World Trade Organization [2013]: World trade report 2013. Factors shaping the future of world trade. pp.11-12. www.wto.org.[17.03.2017]

[12] United Nations [2013]: The Commitment. Linking Landlocked Countries to Global Opportunities. (special future: Gyan Chandra Acharya. Unlocking the Potential of Landlocked developing Countries. [s.a.].p.3.

[13] McQuaid W.R., Greig M., Smyth, Cooper J. [2004]: The Importance of Transport in Business Location Decisions. Napier University, 2004. p.4.

[14] Temjanovski R. [2012]: Towards sustainable transport policy and harmonizing external trade by mode of transport: Macedonian case. Sarajevo: 3rd International Symposium on Sustainable Development 2012, May 31 - June 01 2012, Sarajevo.p. 511-512

[15] State Statistical Office: Statistical Review: Transport. Skopje: State Statistical Office. 2016. [16] National Bank of the Republic of Macedonia [2017]: Basic economic date. [www.nbrm.mk 08.05.2017]

[17] State Statistical Office: External Trade [2017]: Countries with the highest volume of trade with the Republic of Macedonia. 2017 [stat.gov.mk 08.05.2017]

[18] Temjanovski R. [2013]: Transport infrastructure, vital component in the process of European Integration of the Western Balkans - transport geography in spirit of global challenges. Зборник радова са научног скупа: Наука и глобализација, Природно-математичке науке (Пале, 17 19. мај 2013.). p. 335-345. DOI 10.7251/NSFF1408335T 